\title{
10000 a BP 前后北京斋堂东胡林人的生态环境分析
}

\author{
(1) 北京大学城市与环境学院, 北京 100871 ; \\ (2) 北京大学考古文博学院, 北京 100871 \\ E-mail: xiazk@urban.pku.edu.cn
}

夏正楷 ${ }^{(1)}$, 张俊娜 ${ }^{(1)}$, 刘静 ${ }^{(1)}$, 赵朝洪 ${ }^{2}$, 吴小红 ${ }^{2}$

2011-06-07 收稿, 2011-08-05 接受

国家自然科学基金(40571168)和国家科技支撑计划(2010BAK67B02)资助项目

\begin{abstract}
摘要距今 10000 年前后旧石器文化向新石器文化的过渡, 是人类历史上一次重大的事件. 北京斋堂东胡林遗址属于新石器早期人类遗址, 其文化面貌具有明显的新旧石器文化过渡 的性质。同期墓葬中还出土有多具古人骸骨, 被称为“东胡林人”. 配合考古发掘, 在东胡林 遗址进行了地貌第四纪调查和相关沉积物的分析, 就“东胡林人”的生存环境进行了初步的 探讨. 结果表明, “东胡林人”主要生活在 11100 9600 cal a BP 期间, 对应于新仙女木事件结 束之后的升温期, 当时气候环境发生了明显的改善, 出现了温和较干的温带草原与较为温 暖湿润的温带草甸草原交替的植被环境. 文化遗迹的分布部位表明, “东胡林人”主要活动 在河漫滩平原上, 地势平坦、水热条件较好、植被比较茂盛的河漫滩平原适宜于史前人类 生活. 这一研究有助于重建 10000 a BP 前后北京地区的人类生存环境, 也有助于加深对华 北地区新旧石器文化过渡时期环境背景的了解.
\end{abstract} 关键词

东胡林人 新旧石器文化过渡 新仙女木事件 生态环境

“东胡林人”于 2003 年发现于北京市以西约 $60 \mathrm{~km}$ 的斋堂盆地. 该盆地是著名的马兰黄土命名地. 自 1923 年以来, 不少地质学家、地理学家在此做过地貌 和第四纪地质调查, 对这一地区的河流地貌演变、黄 土堆积和地文期等做了大量的工作, 使斋堂盆地成 为研究我国北方地区晚更新世地层和地貌演化的重 要地点 ${ }^{[1 \sim 7]}$.

1966 年郝守刚 ${ }^{[8]}$ 在斋堂盆地东端东胡林村西北 的清水河三级阶地上, 首次发现了一些石化较差的 人骨及贝壳项链, 后经中国科学院古脊椎动物与古 人类研究所清理, 初步认定这是一处新石器时代的 墓葬遗址 ${ }^{[9]}$. 2000 2008 年期间, 北京大学文博学院 和北京市文物研究所联合在此进行了多次考古发掘, 相继出土有石制器、兽骨和早期陶片, 并发现有灰 堆、火塘等用火遗迹, 进一步确认这里是一处新石器 文化早期遗址. 同期的墓葬中还出土了两具完整的
古代人类骸骨, 被称为“东胡林人”. 经 ${ }^{14} \mathrm{C}$ 年龄测定, 遗址主体部分的时代大致为 11100 9600 cal a BP ${ }^{[10]}$.

目前在华北地区已发现的距今 12000 9000 年间 的新石器时代早期遗址有河北徐水南庄头、阳原于家 沟、北京门头沟东胡林、怀柔转年、山西吉县柿子滩 等多处 ${ }^{[11,12]}$, 但其中既有石器、陶器等文化遗物, 又 有用火遗迹及墓葬的仅有东胡林遗址一处. 由于遗 址的年代恰好对应于新仙女木事件(传统文献上为 11000 10000 a BP，最新数据为 12900 11500 a BP) 结束后的全球气候升温期 ${ }^{[13 ~ 16]}$ 和新旧石器文化过渡 的时期 ${ }^{[17]}$, 因此东胡林遗址和“东胡林人”的发现引 起了国内外学术界的广泛关注. 本文希望能通过对 遗址古环境的深人研究, 进一步揭示新旧石器文化 过渡的性质及其环境背景.

2002 年, 郝守刚等人 ${ }^{[18]}$ 通过对遗址附近黄土剖 面的分层、粒度特征、矿物成分、化学成分、孢粉图

英文版见: Xia Z K, Zhang J N, Liu J, et al. Analysis of the ecological environment around 10000 a BP in Zhaitang area, Beijing: A case study of the Donghulin Site. Chinese Sci Bull, 2011, 56, doi: 10.1007/s11434-011-4772-9 
谱及蜗牛相对丰度等多方面的研究, 认为本地区晚 更新世的气候比较干冷, 气候的明显转暖出现在 $9281 \pm 120$ a BP 之前, 到 8500 a BP 前后, 华北地区的 年均温度可能已比现在高 $2 \sim 3{ }^{\circ} \mathrm{C}$. 并提出正是在这样 的环境背景下, 山顶洞人的后裔们, 在清水河畔的阶 地上开始了全新的生活. 由于当时遗址尚未正式发 掘, 遗址的地貌结构、堆积地层和古文化的性质都还 不十分清楚, 因此, 这一工作只能是初步的研究, 与 后来揭示的遗址具体情况有一定的出人, 不能真正 反映东胡林人的生存环境. 2000 2008 年, 我们结合 遗址的发掘过程, 再次开展了遗址的古地貌和古环 境研究, 以便深人了解当时人类的生存环境, 为探讨 新旧石器文化过渡提供环境背景.

\section{1 东胡林遗址的地貌结构分析}

东胡林遗址位于北京斋堂盆地东端的东胡林村 西北, 永定河的主要支流——清水河自西向东从村 南流过, 河床海拔高程 $360 \mathrm{~m}$. 在河流北侧的基岩山 坡上，发育有黄土台地和三级河流阶地.

黄土台地高于河床约 $32 \mathrm{~m}$, 台地面宽 16 100 m 不等, 已被人工改造成梯田, 其前缘为高 $2 \sim 4 \mathrm{~m}$ 不等的 黄土陡坎, 后缘与基岩山坡相连. 台地主要由马兰黄土 组成, 其中夹有两层古土壤, 上古土壤层厚 $0.50 \mathrm{~m}$, 浅 棕红色, 质地致密, 热释光年龄为距今 $21.05 \pm 0.41 \mathrm{ka}$, 下古土壤层厚 $0.50 \mathrm{~m}$, 棕红色, 质地致密, 热释光年 龄为距今 $62.9 \pm 1.93 \mathrm{ka}^{[18]}$. 台地顶部披盖有厚 $1 \sim 2 \mathrm{~m}$ 的全新世黄土.

黄土台地面之下发育有三级河流阶地, 其中第 三级阶地宽 $30 \mathrm{~m}$ 左右, 高于河床 $24 \mathrm{~m}$, 阶地堆积物 具有明显的二元结构, 厚 4 5 m, 它坐落在黄土台地
前缘，属于以马兰黄土为基底的基座阶地. 东胡林遗 址位于这级河流阶地, 其文化层主要分布在组成阶 地的河流堆积物之中(图 1).

\section{2 东胡林遗址的剖面特征}

东胡林遗址的代表性剖面见于遗址东区的 $\mathrm{T} 8$ 探 方西壁，该剖面厚 $5.86 \mathrm{~m}$ ，根据岩性特征，可以将该 剖面由上而下划分为 12 层:

1. 灰黄色粉砂, 质地疏松, 垂直节理发育, 含有小 钙结核, 其中夹有古土壤层 $\left(\mathrm{L}_{0} \mathrm{~S}\right)$. 属全新世黄 土.

$150 \mathrm{~cm}$

2. 灰黄色粉砂, 偶见小砾石及钙结核. 含少量炭 屑和石制品.

$36 \mathrm{~cm}$

3. 褐灰色黏土, 质地较硬, 下部含有零星砾石. 含 石器、动物骨骼和碳屑等文化遗物. $16 \mathrm{~cm}$

4. 灰黄色粉砂, 含有较多的白色碳酸盐假菌丝, 可见褐色团块, 偶见 $0.5 \mathrm{~mm}$ 左右的小砾石. 本 层未见文化遗物.

$36 \mathrm{~cm}$

5. 褐灰色黏土质粉砂, 夹有较多的 $1 \sim 2 \mathrm{~cm}$ 的砾石, 偶夹较大的灰岩角砾, 砾径 5 6 cm. 含有碎骨、螺 壳、碳屑以及少量的红烧土颗粒等文化遗物. 在 整个遗址区, 本层顶面上分布有较多的灰堆和 灰坑, 为当时人类的活动面.

$60 \mathrm{~cm}$

6. 褐黄色细砂, 夹有较多的细小砾石, 小型微斜层理 发育, 顶面出现有小型沙波, 含有大量螺壳. 本层 不含文化遗物，仅有一墓葬开口于本层顶面.

7. 褐黄色细砂, 偶见小砾石, 具明显的小型斜层 理，夹有少量螺壳. 靠近北侧本层顶面分布有一 直径 $80 \mathrm{~cm}$, 高 $16 \mathrm{~cm}$ 的灰堆.

$12 \mathrm{~cm}$

8. 棕褐色黏土质粉砂, 可见较多的白色碳酸盐假菌 丝, 偶见磨圆砾石. 本层中发现的文化遗物最为

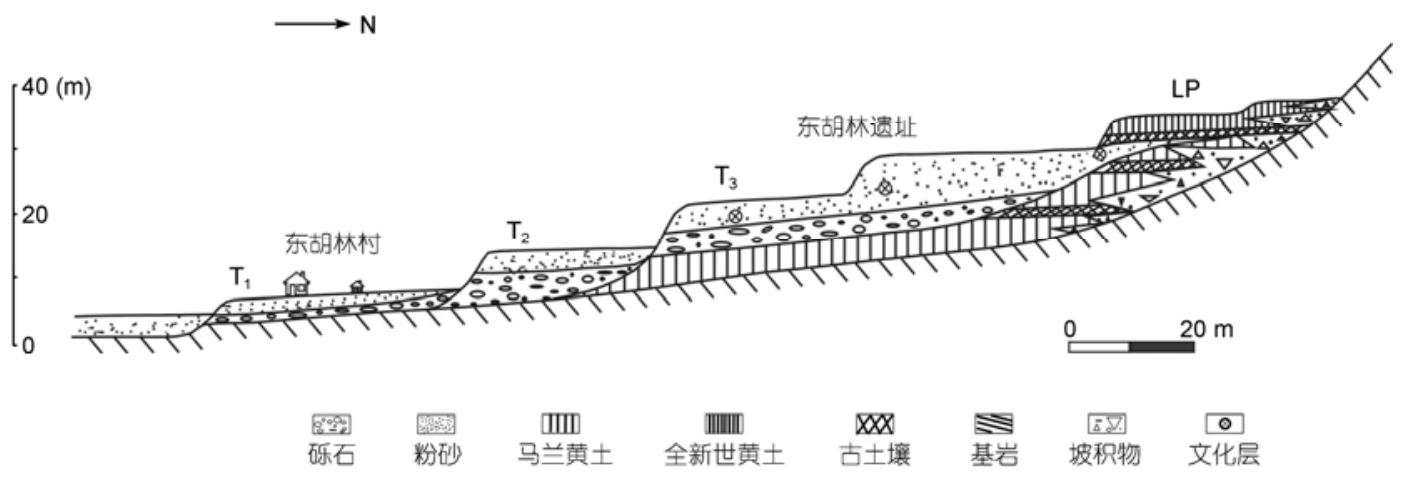

图 1 斋堂东胡林遗址地貌结构图 
丰富, 有石磨盘、陶片和动物骨骼、人骨、螺壳、 炭屑等. 在整个遗址区, 本层顶面分布有较多 的灰堆, 属于当时人类的活动面. $28 \mathrm{~cm}$

9. 棕褐色黏土质粉砂, 含有较多的白色假菌丝体, 致密块状, 局部具水平层理, 偶见灰绿色小角砾 和灰白色钙结核. 出土有少量兽骨、螺壳、炭屑. 整个遗址区本层顶面分布有灰坑、灰堆, 并有一 墓葬开口于本层顶面, 为当时人类的活动面.

$56 \mathrm{~cm}$

10. 棕黄灰色粉砂, 质地坚硬, 颜色较暗, 含有大量 的碳酸盐斑点和结核, 偶见砾径 $2 \mathrm{~mm}$ 左右的小 砾石.

$16 \mathrm{~cm}$

11. 砾石层, 夹有薄层泥质粉砂, 砾石成分复杂, 有 灰绿-紫红色火山岩、灰岩等, 砾径 2 5 cm, 分选 较好, 磨圆 II III 级.

$60 \mathrm{~cm}$

12. 灰黄色马兰黄土, 其中夹有棕红色古土壤层, 与 上覆地层之间存在有明显的侵蚀面, 属于阶地 的基座.

$100 \mathrm{~cm}$

从上述描述可以看出, 探方剖面中第 2 11 层属 于组成三级阶地的河流堆积物. 河流堆积之上的剖 面第 1 层为全新世黄土堆积, 属于阶地形成之后的风 尘堆积, 河流堆积之下的第 12 层为马兰黄土堆积, 属于阶地的基座.

年代测试表明, 河流堆积物靠底部的第 9 层, 其 $\mathrm{AMS}^{14} \mathrm{C}$ 年龄为 $9570 \pm 70 \mathrm{a} \mathrm{BP}$, 经树轮校正为 11090 $\mathrm{cal} \mathrm{a} \mathrm{BP}$, 靠顶部的第 2 层, 其 $\mathrm{AMS}{ }^{14} \mathrm{C}$ 年龄为 $8535 \pm$ $80 \mathrm{a} \mathrm{BP}$, 经树轮校正为 $9560 \mathrm{cal} \mathrm{a} \mathrm{BP}($ 表 1). 说明河 流的下切发生在 $11090 \mathrm{cal} \mathrm{a} \mathrm{BP}$ 前后, 阶地堆积物形
成于 11100 9600 cal a BP 期间, 对应于新仙女木事 件之后的升温期, 东胡林人活动的遗迹主要分布在 河流堆积物之中. 为了探索东胡林人的生存环境, 本 文主要选择这套河流堆积作为研究对象, 采集系列 样品, 在室内进行了沉积物的粒度分析和孢粉分析, 以获取更多的古环境信息.

\section{3 粒度分析}

通过河流沉积物的粒度分析获取沉积物的粒度 参数和粒度曲线, 并以此为根据对河流堆积物进行 沉积相和微相的划分, 是研究河流水文动态和地貌 演化过程的重要手段 ${ }^{[20]}$. 东胡林遗址的人类活动遗 迹分布在河流堆积物之中, 且出现在沉积剖面的不 同层位，因此，通过系统的粒度分析，可以了解不同 时期人类活动的地貌部位和遗址所在位置的河流地 貌演变过程，进而揭示古人类活动的地貌环境.

粒度分析的样品采自上述遗址剖面的第 2 10层， 每个样品长 $4 \mathrm{~cm}$, 连续采集沉积物样品 68 个, 共计 $272 \mathrm{~cm}$ (剖面第 11 层是砾石层, 为典型的河床相堆积, 故没有进行粒度分析). 粒度分析在 RS1000 型粒度自 动分析仪上进行. 通过粒度分析, 获取了全部样品的 粒度参数和粒度曲线.

\section{1 粒度参数特征}

我们选取平均粒径、众数粒径、中值粒径和标准 离差、分选系数、偏度、尖度等粒度参数, 按层位求 得各层的平均值(表 2).

\section{表 1 遗址剖面的 $\mathrm{AMS}^{14} \mathrm{C}$ 年代测试数据 ${ }^{\mathrm{a})}$}

\begin{tabular}{|c|c|c|c|c|c|}
\hline \multirow{2}{*}{ 层位 } & \multirow{2}{*}{ 实验室编号 } & \multirow{2}{*}{ 材料 } & \multirow{2}{*}{$\mathrm{AMS}^{14} \mathrm{C}$ 年龄 $(\mathrm{a} \mathrm{BP})$} & \multicolumn{2}{|c|}{$\begin{array}{c}\text { 树轮校正年龄 ( cal a BP) } \\
\end{array}$} \\
\hline & & & & $68.2 \%$ 置信度 & $95.4 \%$ 置信度 \\
\hline 2 & BAO7788 & 木炭 & $8535 \pm 80$ & $9560(68.2 \%) 9440$ & $\begin{array}{l}9350(1.1 \%) 9320 \\
9700(95.4 \%) 9400\end{array}$ \\
\hline 3 & BA05890 & 木炭 & $8775 \pm 40$ & $9890(68.2 \%) 9690$ & $\begin{array}{l}10150(2.3 \%) 10050 \\
9950(93.1 \%) 9550\end{array}$ \\
\hline 4 & BA02146 & 木炭 & $8780 \pm 90$ & $\begin{array}{l}10150(6.3 \%) 10050 \\
9950(61.9 \%) 9600\end{array}$ & $10200(95.4 \%) 9550$ \\
\hline 5 & BAO5891 & 木炭 & $8805 \pm 50$ & $\begin{array}{l}10120(7.2 \%) 10090 \\
9920(65.5 \%) 9700\end{array}$ & $10200(95.4 \%) 9600$ \\
\hline 7 & BA05887 & 木炭 & $9155 \pm 40$ & $\begin{array}{l}10380(26.5 \%) 10310 \\
10300(41.7 \%) 10240\end{array}$ & $\begin{array}{l}10480(1.2 \%) 10460 \\
10430(94.2 \%) 10230\end{array}$ \\
\hline 8 & BA02150 & 木炭 & $9180 \pm 80$ & $\begin{array}{l}10480(2.3 \%) 10460 \\
10420(65.9 \%) 10240\end{array}$ & $10560(95.4 \%) 10220$ \\
\hline 9 & BA03420 & 人骨 & $9570 \pm 70$ & $\begin{array}{l}11090(38.4 \%) 10920 \\
10890(29.8 \%) 10860\end{array}$ & $11170(95.4 \%) 10700$ \\
\hline
\end{tabular}

a) 由北京大学年代学实验室和加速器质谱实验室测定, 所用碳 14 半衰期为 5568 年, BP 为距 1950 年的年代. 树轮校正所用曲线为 IntCal04 $4^{[19]}$, 所用程序为 OxCal v3.10(http://rlaha.ox.ac.uk/orau.html) 
结果显示, 粒度参数的变化与野外剖面观察完 全一致：以第 8 层顶面为界, 这套河流堆积物可以分 为两部分, 其中下部的第 8 10 层, 具有剖面中最细 的粒度和最差的分选状况, 它和其下伏的第 11 层砂 砾石共同组成一个下粗上细的粒度旋回; 而上部的 第 6 7 层具有剖面中(除砂砾石层之外)最粗的粒度和 最好的分选, 向上第3 5层粒度明显变细, 分选变差, 也组成一个下粗上细的粒度旋回(图 2).

\section{2 粒度曲线特征}

粒度分析结果表明, 所有 68 个样品的频率曲线 和概率累积曲线图按其特征可以明显地划分为 $\mathrm{A}, \mathrm{B}$ 两种不同的类型, 其中 $\mathrm{B}$ 类型又可以进一步划分为
两种亚类，它们分别指示不同的沉积环境 ${ }^{[21 ~ 23]}$ (表 3).

(i ) 类型 A. 此类样品粒度较粗, 细砂成分较 多. 其粒度频率曲线为双峰态, 正偏态, 主峰位置在 4 4.5 $\Phi$ 左右, 粗尾端陡, 并在 $-1 \sim 1$ Ф之间出现一低 峰, 细尾端上段陡, 下段较缓，在 6 7 $\Phi$ 之间出现一 和缓的平台. 粒度概率累积曲线呈三段式, 推移段 $(-1.0 \sim 1.0 \Phi)$ 占 $1 \% \sim 5 \%$, 斜率大，分选好; 跃移段 $(1 \sim 5.0 \Phi)$ 约占 $60 \%$ 70\%, 由斜率不同的两段组成, 反映水流的往复作用; 悬移段 $(>5.0 \Phi)$ 约占 $30 \%$, 斜 率小, 分选差. 粒度频率曲线上粗尾端次高峰的出现、 粒度概率累积曲线图上推移组分的存在以及跃移段 占主要组分，且由斜率不同的两段构成等特征，指示 水流流速较急, 颗粒主要以跃移方式运移, 并受水流

表 2 剖面 2 10 层粒度参数平均值

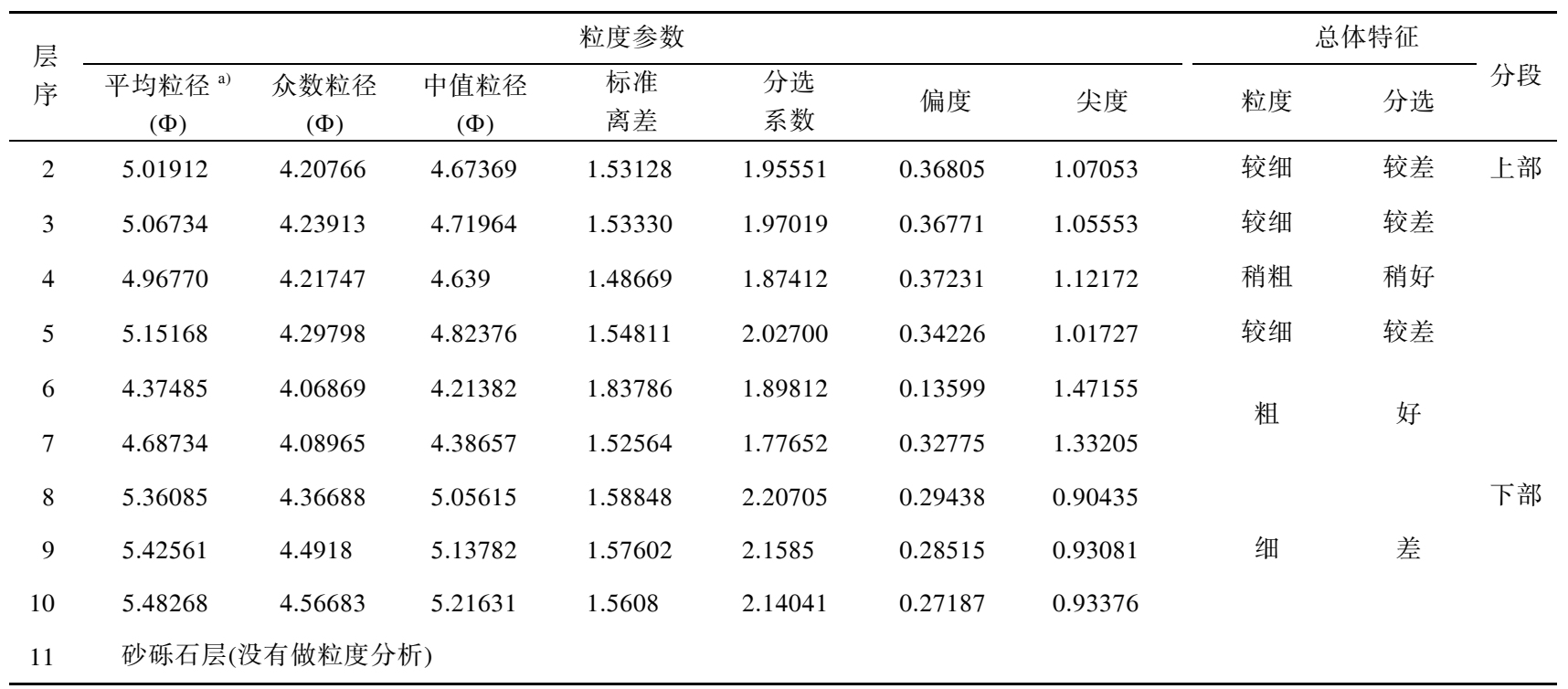

a) $\Phi$ 的计算使用的是克伦宾 (Krumbein,1934)根根乌登-温特沃思粒级 (Udden-Wentworth scale)，通过对数变换而来的公式 ${ }^{[21]}$, 定义为 $\Phi=$ $-\log _{2} d(d$ 是颗粒直径, 单位: $\mathrm{mm})$

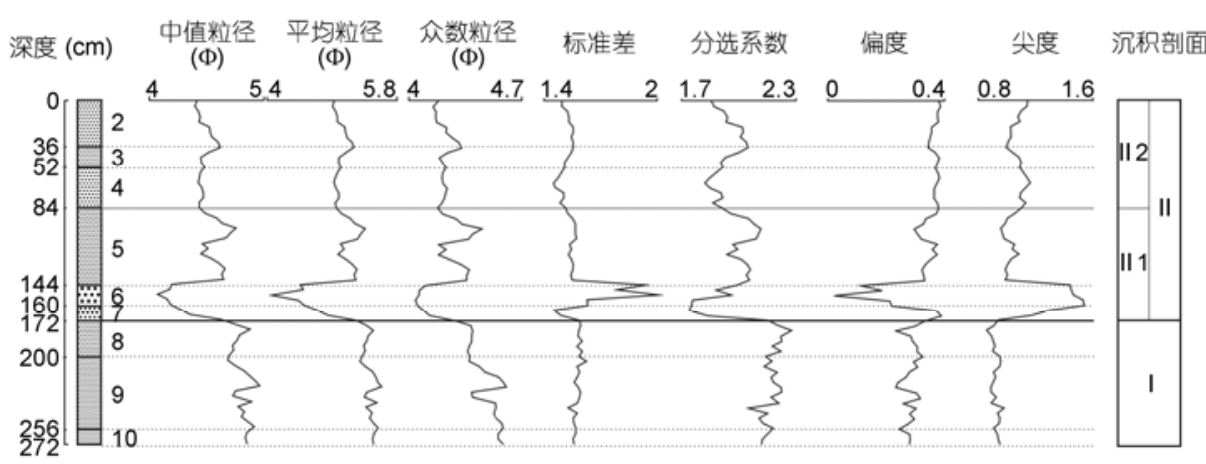

图 2 剖面 2 10 层粒度参数变化曲线图 
表 3 剖面中 3 种不同沉积类型的粒度曲线特征

\begin{tabular}{|c|c|c|c|c|c|c|c|c|c|c|c|}
\hline \multirow{2}{*}{ 类型 } & \multicolumn{5}{|c|}{ 粒度频率曲线特征 } & \multicolumn{4}{|c|}{ 粒度概率曲线特征 } & \multirow{2}{*}{ 分布层位 } & \multirow{2}{*}{ 沉积环境 } \\
\hline & 峰态 & 主峰 $(\Phi)$ & 偏态 & 粗端 & 细端 & 图式 & 推移段(Ф) & 跃移段 $(\Phi)$ & 悬移段 $(\Phi)$ & & \\
\hline A & 双峰 & $\begin{array}{l}4.3 \\
\text { 较窄 }\end{array}$ & 正 & $\begin{array}{l}\text { 陡立 } \\
\text { 次峰 }\end{array}$ & $\begin{array}{l}\text { 斜直 } \\
\text { 平台 }\end{array}$ & 三段 & $\begin{array}{l}-1.0 \sim 1.0 \\
(2 \% \sim 5 \%)\end{array}$ & $\begin{array}{l}1 \sim 5.0 \\
(70 \%)\end{array}$ & $\begin{array}{l}>5.0 \\
(30 \%)\end{array}$ & 第 6 7 层 & 河床边滩 \\
\hline B1 & 单峰 & $\begin{array}{l}4.5 \\
\text { 较宽 }\end{array}$ & 正 & 陡立 & 斜直 & 两段 & 无 & $\begin{array}{c}2.3 \sim 5.0 \\
(50 \%)\end{array}$ & $\begin{array}{l}>5.0 \\
(50 \%)\end{array}$ & $\begin{array}{l}\text { 第 } 5 \text { 层下部, } \\
\text { 第 9 10 层 }\end{array}$ & $\begin{array}{c}\text { 漫滩 } \\
\text { 近岸环境 }\end{array}$ \\
\hline B2 & 单峰 & $\begin{array}{c}4.5 \\
\text { 较窄 }\end{array}$ & 正 & 陡立 & $\begin{array}{l}\text { 斜直 } \\
\text { 平台 }\end{array}$ & 两段 & 无 & $\begin{array}{c}2.3 \sim 5.0 \\
(50 \%)\end{array}$ & $\begin{array}{l}>5.0 \\
(50 \%)\end{array}$ & $\begin{array}{c}\text { 第 2 4 层, 第 } 5 \text { 层 } \\
\text { 上部, 第 } 8 \text { 层 }\end{array}$ & $\begin{array}{c}\text { 漫滩 } \\
\text { 远岸环境 }\end{array}$ \\
\hline
\end{tabular}

往复运动的影响, 出现不同斜率的两部分, 属于河床 相的边滩堆积(图 3(a), (b)). 类型 A 仅分布于第 6 和 7 层.

(ii) 类型 B. 此类样品粒度较细, 以粉砂为主. 其粒度频率曲线为单峰态, 主峰位置在 4.5 左右, 正偏态, 曲线粗端陡, 细端上半段 (4.5 6.0 $\Phi)$ 较陡, 下半段(6 10 $\Phi)$ 较缓. 粒度概率累积曲线图呈两段式, 主要由跃移总体和悬移总体两部分构成, 缺乏推移 组分, 跃移组分 $(2.3 \sim 5.0 \Phi)$ 约占 40\% 50\%, 由斜率不 同的两段组成，反映水流的往复作用; 悬移组分 $(>5.0 \Phi)$ 约占 $50 \%$, 斜率小, 分选差; 根据样品中缺 乏推移组分, 跃移组分由斜率不同的两段组成, 且与
悬浮组分的含量大体相当等特征, 应属于河漫滩堆积. 进而根据粒度曲线特征可以把类型 $\mathrm{B}$ 分为两个 亚类, 其中 B1 亚类的粒度频率曲线主峰较宽, 细段 部分为一圆滑曲线, 属递变悬浮, 反映分选不佳的悬 浮环境, 属于近岸的河漫滩堆积(图 3(c), (d)), 剖面 中主要见于第 9 10 层和第 5 层下部; B2 亚类的粒度 频率曲线的主峰较窄，细段部分在 6 8 $\Phi$ 之间出现一 明显的平台, 反映分选较好的悬浮环境, 属于离岸较 远的河漫滩堆积(图3(e),(f)), 剖面中主要见于第 8 层、 第 5 层上部和第 2 4 层.

根据以上粒度分析结果，并结合野外实地观察， 可以把剖面中的河流堆积物分为上下两部分，其中
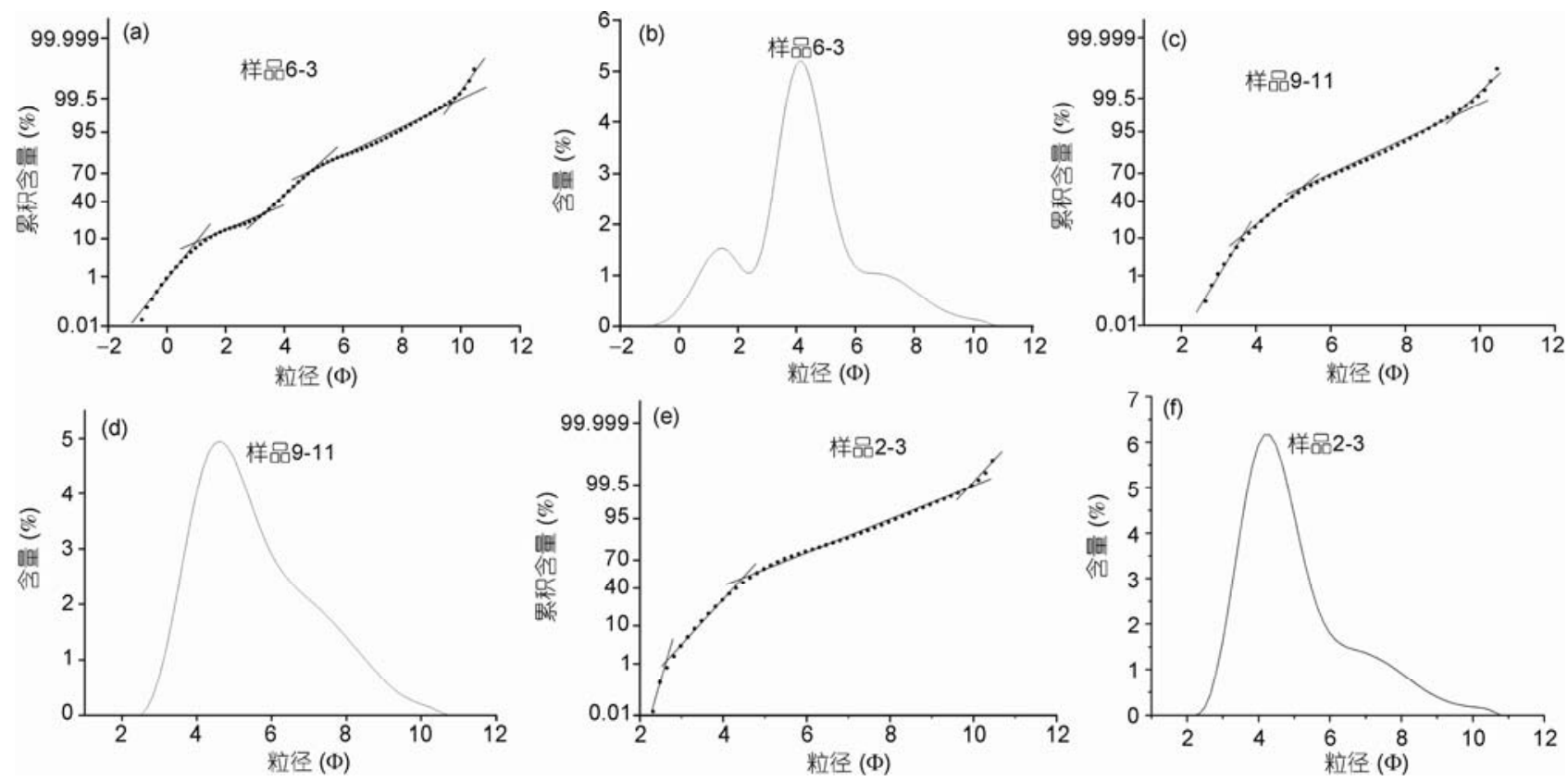

图 3 不同类型沉积物的代表性粒度概率曲线和频率曲线

(a) 类型 $\mathrm{A}$ 河床边滩沉积的粒度概率累积曲线; (b) 类型 $\mathrm{A}$ 河床边滩沉积的粒度频率曲线; (c) 类型 B1 漫滩近岸沉积的粒度概率累积曲线; (d) 类型 B1 漫滩近岸沉积的粒度频率曲线; (e) 类型 B2 漫滩远岸沉积的粒度概率累积曲线; (f) 类型 B2 漫滩远岸沉积的粒度频率曲线 
下部从底砾层(第 11 层)开始到第 8 层, 代表一次从河 床主流堆积(第 11 层)——河漫滩近岸堆积(第 9 10 层)——河漫滩远岸堆积(第 8 层)的河流过程; 上部从 第 7 层开始到第 2 层, 代表另一次从河床边滩相(第 6 7 层)——河漫滩近岸堆积(第 5 层)——河漫滩远岸 堆积(第 2 4 层)的河流过程. 两者的分界根据第 8 层 的测年数据, 大致在 $10500 \mathrm{cal} \mathrm{a} \mathrm{BP}$ 左右. 人类活动 遗迹的分布表明, 东胡林人主要活动在两次河漫滩 发育阶段, 尤其是远岸河漫滩发育阶段。他们生活在 洪水后退之后出露的河漫滩平原上, 并随着河水的 涨落和由此引起的地貌变化, 不断改换之间的营地, 过着半定居的生活.

\section{4 抱粉分析}

孢粉分析可以反映区域植被的组成及其变化情 况，是恢复古生态、古气候的重要手段.

我们在东胡林人遗址探方 8 北壁剖面上，与粒度 分析样品同步, 从第 10 层底部到第 2 层顶部, 按样长 $4 \mathrm{~cm}$, 连续采集样品 68 个. 在采集过程中我们注意避 开了古人类的活动面, 以尽量减少人类干扰的影响.

样品经酸碱处理、д-6 重液(比重 2.13)浮选, 共鉴 定出 31 个科属, 包括木本植物花粉 12 个科属, 有松 属(Pinus)、柏科(Pressaceae)、桦属(Betula)、鹅耳杵 属(Carpinus)、栋属(Quercus)、胡桃属(Juglans)、椴 属(Tilia)、榆属(Ulmus)、漆树属(Rhus)、柳属(Salix)、 桑科(Moraceae)、木犀科(Oleaceae); 草本植物花粉 17 个科属, 有蒿属(Artemisia)、藜科(Chenopodiaceae)、禾 本科(Gramineae)、菊科(Compositae)、毛茛科(Ranunculaceae)、唐松草属(Thalictrum)、唇形科(Labiaceae)、 苶属(Polygonum)、蓄薇科(Rosaceae)、玄参科(Scrophulariaceae)、旋花科(Convolulaceae)、律草属(Humulus)、 豆科(Leguminosae)、茄科(Solanaceae)、十字花科(Cruciferae)、莎草科(Cyperaceae)、大戟科(Euphorbiaceae); 茨类植物狍子 2 个科属, 有卷柏属 (Selaginella)、水龙 骨科(Polypodiaceae). 这些都是当地目前常见的植物 种属.

狍粉分析的结果表明, 所有 68 个样品的孢粉浓 度均偏低,一般不超过 23 粒 $/ \mathrm{g}$, 说明当时植被比较稀 疏. 样品中草本植物花粉、木本植物花粉和蓱类植物 孢子的百分含量相对比较稳定, 其中草本植物一直 占绝对优势，一般在 80\% 90\%左右，最高可达 100\%， 主要以蒿属为主, 藜科和禾本科次之, 绝大多数样品
的 A/C 值都大于 1 . 木本植物不多，一般占 $0 \sim 20 \%$, 主要为松柏类和落叶阔叶树, 后者略高于前者. 部分 样品中还出现有少数的偋类植物狍子( 0 3.7\%), 可能 与河漫滩上残留的水洼地有关. 通常认为, 草本植物 和阔叶树的花粉飞翔能力低, 基本上落在原地或附 近, 只有松属的花粉由于具有特殊的气囊, 飞翔能力 强, 可以到达比较远的地方 ${ }^{[24]}$. 上述东胡林遗址的 花粉组合中, 松属花粉所占比例极少, 草本植物一直 占绝对优势, 因此我们认为它基本上可以反映当时 东胡林一带的植被面貌.

根据主要狍粉百分含量特征, 可将第 2 9 层由上 而下划分为以下 7 个孢粉带(图 4, 表 4):

第 I 孢粉带: 深度 $0 \sim 52 \mathrm{~cm}$, 对应于第 2 层和第 3 层. 本带孢粉浓度 6.3\% 47.8\%. 草本植物为主, 占 $71.1 \%$ 100\%, 以蒿属为主, 占 $44.3 \% \sim 61.9 \%$, 藜科、禾 本科次之, 分别占 $3.6 \%$ 20.4\%和 $6.0 \%$ 21.4\%, A/C 值较高 $(2.28 \sim 16.00)$, 此外还有菊科、毛茛科、唐松草 属、蓄薇科、茄科、十字花科、豆科、律草科、旋花 科和莎草科等; 木本植物占 $0 \sim 26.8 \%$, 主要为落叶阔 叶树, 如桦属、鹅耳枥属、栎属、胡桃属、榆属、漆 树属、柳属、桑科和木樨属等, 还有少量松属和柏科; 䓲类植物占 $0 \sim 2.9 \%$, 有卷柏属、水龙骨科, 分布比较 普遍. 指示比较温暖湿润的温带草甸草原植被.

第 II 孢粉带: 52 120 cm，对应第第 5 层上部和第 4 层. 本带狍粉浓度 8.1 18.4 粒/g. 草本植物占绝对 优势，占 $88.2 \%$ 100\%，以蒿属为主，占 $36.4 \%$ $70.4 \%$, 藜科次之, $(11.1 \% ~ 39.4 \%)$, 禾本科再次之 (2.8\% 22.9\%), A/C 值较高( $0.83 \sim 6.33)$, 还有少数的 毛莨科、唐松草属、茄科、十字花科、豆科、律草、 玄参科、唇形科等. 木本植物少量, 仅占 $0 \sim 11.5 \%$, 只 有松属和零星的漆树属、桑科等. 偋类植物仅有卷柏 属, 占 0 3.4\%, 仅出现在个别层位. 指示温和较干的 温带草原植被.

第 III 狍粉带: 120 144 cm，对应于第 5 层下部. 孢粉浓度 $10.2 \sim 22.8$ 粒/g. 草本植物仍占优势 (83.3\% 90.2\%), 以蒿属为主, 占 $51.2 \% \sim 65.5 \%$, 藜科 次之 $(8.6 \%$ 26.8\%), 禾本科较少 $(3.7 \%$ 7.9\%), $\mathrm{A} / \mathrm{C}$ 值 较高(1.91 7.60), 此外还有毛莨科、唐松草属、豆科、 苶属、茄科及十字花科、律草属、旋花科、玄参科、 唇形科等. 木本植物花粉有所增加, 占 $9.8 \%$ 16.7\%, 出现较多的落叶阔叶树, 有柇属、桦属、椴属、鹅耳 枥属、漆树属、桑科, 还有少数的松属; 没见蕨类植 


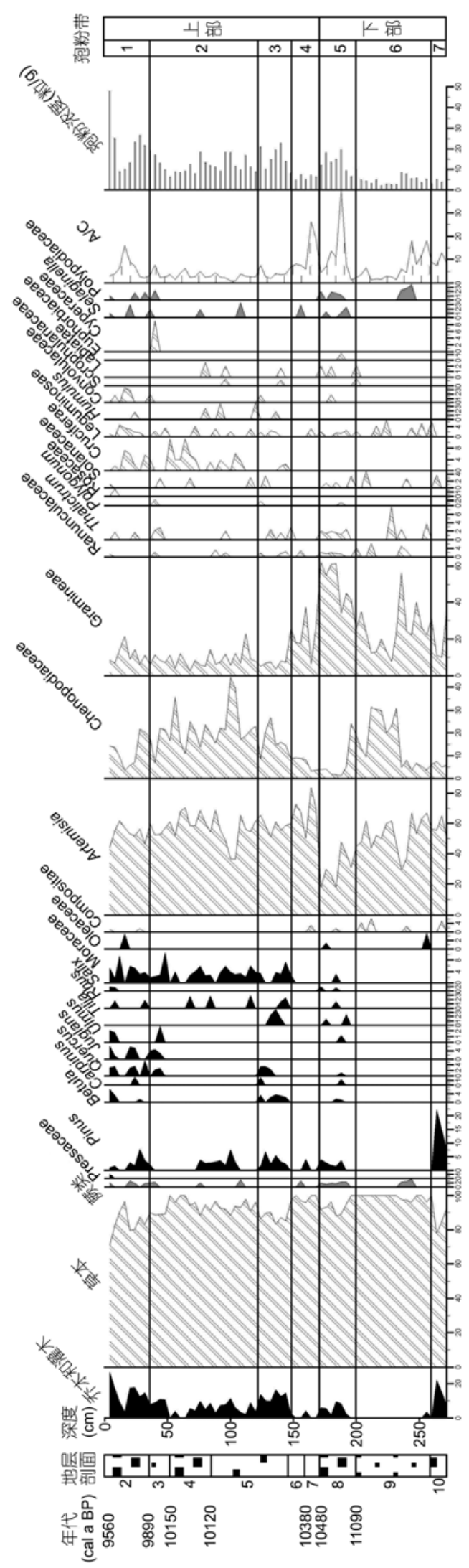

图 4 东胡林遗址剖面孢粉图
物. 指示比较温暖湿润的温带草甸草原植被.

第 IV 孢粉带: 深度 144 172 cm，对应第 6 和第 7 层. 本带孢粉浓度 4.8 12 粒/g. 草本植物占绝对优势 $(92 \% \sim 100 \%)$, 以蒿属为主，占 $18 \% \sim 83.9 \%$, 禾本科 次之 $(6.5 \% \sim 62 \%)$, 藜科少数 $3.2 \% \sim 9.1 \%, \mathrm{~A} / \mathrm{C}$ 值较高 (4.50 26.22), 还有少数的菊科、毛茛科、唐松草属、 豆科、唇形科等; 木本植物少量，仅占 $0 \sim 6.0 \%$ ，只有 零星的松属和桑科. 蕨类植物比例仅占 $0 \sim 2.9 \%$, 只 有零星的卷柏属和水龙骨科. 指示温和较干的温带 草原植被.

第 V 孢粉带：深度 172 200 cm，对应第 8 层. 本 层孢粉浓度 6.5 19.6 粒/g. 草本植物仍占绝对优势, 达 $88.7 \%$ 100\%, 以禾本科为主 $(25.5 \%$ 61.3\%), 蒿属 次之 $(17.7 \% \sim 44.7 \%)$, 藜科少数 $(1.2 \%$ 24.1\%), A/C 值 较高(1.28 39.67), 还有毛茛科、唐松草属、蓼科、菊 科、豆科、茄科、旋花科、唇形科、大戟科、玄参科 等; 木本植物有所增加, 占 $0 \sim 9.7 \%$, 出现较多的落叶 阔叶树种, 如桦属、我耳枥属、栎属、榆属、椴属、柳 属、眿树属、桑科、木樨科等，还有少量的松属；蕨 类植物也有所增加(占 $0 \sim 2.5 \%$ ), 主要为水龙骨科和 卷柏属. 指示比较温暖湿润的草甸草原植被.

第 V孢粉带：深度 200 256 cm，对应第 9 层. 本 带孢粉浓度 2.0 8.6 粒/g. 草本植物占 96.3\% 100\%, 主要为蒿属 $(29.3 \% \sim 66.7 \%)$, 禾本科 $(7.7 \% \sim 56.1 \%)$ 和 藜科(3.7\% 30.8\%)次之, A/C 值较高(1.40 18.03), 同 时出现有少数中生草本植物, 如菊科、毛茛科、唐松 草属、豆科、茄科等. 木本植物仅见个别木樨科，萍 类植物见于中部, 仅水龙骨科. 指示温和较干的温带 草原.

第 VII孢粉带：深度 256 272 cm，对应第 10 层. 本带孢粉浓度 $3.1 \sim 10.1$ 粒/g, 草本植物为主, 占 $77.8 \% \sim 100 \%$, 以蒿属为主 $(51 \% \sim 65 \%)$, 禾本科次之 $(10.0 \%$ 35.3\%), 藜科少数 $(5.0 \% \sim 7.4 \%)$, 还有少量豆 科、茄科, $\mathrm{A} / \mathrm{C}$ 值较高 (7.51 13.00); 木本植物 0 $22.2 \%$, 全部为松属; 未见蕨类植物. 指示温凉较干 的温带草原.

从以上孢粉组合的总体特征来看，在东胡林人 活动期间(11100 9600 cal a BP), 这一地区的植被主 要以蒿属为主, 藜科或禾本科次之, 间有阔叶落叶树 出现, 属于温和较干的温带草原与比较温暖湿润的 温带草甸草原交替出现的生态环境, 其中比较温暖 湿润的温带草甸草原更多的出现在东胡林人活动的 
表 4 各狍粉带的狍粉组合特征及生态环境

\begin{tabular}{|c|c|c|c|c|c|c|c|}
\hline \multirow{2}{*}{ 剖面 } & \multirow{2}{*}{ 孢粉带 } & \multirow{2}{*}{ 层位 } & \multicolumn{4}{|c|}{ 孢粉组合特征 } & \multirow{2}{*}{ 生态环境 } \\
\hline & & & 草本植物 & 木本植物 & 蕨类植物 & 蒿藜比(A/C) & \\
\hline \multirow[t]{4}{*}{ 上部 } & I & $3 \sim 2$ & $\begin{array}{l}71.1 \% \text { 100\% } \\
\text { 蒿-禾本-㢣, 其他多种中生草本 }\end{array}$ & $\begin{array}{l}0 \sim 26.8 \% \\
\text { 较多松属和落叶阔叶树出现(8 种) }\end{array}$ & 较多 & $\begin{array}{c}2.28 \sim 16.00 \\
\text { 均值 } 5.41\end{array}$ & $\begin{array}{l}\text { 比较温暖湿润的 } \\
\text { 温带草甸草原 }\end{array}$ \\
\hline & II & $5_{\text {上 }} \sim 4$ & $\begin{array}{l}88.2 \% \text { 100\% } \\
\text { 蒿-黎-禾本, 其他中生草本少量 }\end{array}$ & $\begin{array}{l}0 \sim 11.5 \% \\
\text { 有少量的松属和落叶阔叶树(漆、桑) }\end{array}$ & 个别 & $\begin{array}{l}0.83 \sim 6.33 \\
\text { 均值 } 2.96\end{array}$ & $\begin{array}{l}\text { 温和较干的温带 } \\
\text { 草原 }\end{array}$ \\
\hline & III & 5 下 & $\begin{array}{l}83.3 \% \text { 90.2\% } \\
\text { 蒿-黎-禾本, 其他多种中生草本 }\end{array}$ & $\begin{array}{l}9.8 \% \text { 16.7\% } \\
\text { 有较多的松属和落叶阔叶树(6 种) }\end{array}$ & 未见 & $\begin{array}{l}1.91 \sim 7.60 \\
\text { 均值 } 3.99\end{array}$ & $\begin{array}{l}\text { 比较温暖湿润的 } \\
\text { 温带草甸草原 }\end{array}$ \\
\hline & IV & $7 \sim 6$ & $\begin{array}{l}92 \% \text { 100\% } \\
\text { 蒿-禾本-黎, 其他中生草本少量 }\end{array}$ & $\begin{array}{l}0 \sim 2.9 \% \\
\text { 仅有少数松属和零星落叶阔叶树(柳) }\end{array}$ & 少量 & $\begin{array}{l}4.50 \sim 26.22 \\
\text { 均值 } 11.20\end{array}$ & $\begin{array}{l}\text { 温和较干的温带 } \\
\text { 草原 }\end{array}$ \\
\hline \multirow[t]{3}{*}{ 下部 } & $\mathrm{V}$ & 8 & $\begin{array}{l}88.7 \% \text { 100\% } \\
\text { 禾本-高-㢣-其他多种中生草本 }\end{array}$ & $\begin{array}{l}0 \sim 9.7 \% \\
\text { 有少量的松属和落叶阔叶树(4 种) }\end{array}$ & 较多 & $\begin{array}{l}1.28 \sim 39.67 \\
\text { 均值 } 11.86\end{array}$ & $\begin{array}{l}\text { 比较温暖湿润的 } \\
\text { 温带草甸草原 }\end{array}$ \\
\hline & VI & 9 & $\begin{array}{l}96.3 \% \text { 100\% } \\
\text { 蒿-禾本-黎, 其他中生草本少量 }\end{array}$ & $\begin{array}{l}0 \sim 3.7 \% \\
\text { 未见松属和落叶阔叶树种 }\end{array}$ & 个别 & $\begin{array}{l}1.40 \sim 18.03 \\
\text { 均值 } 6.33\end{array}$ & $\begin{array}{l}\text { 温和较干的温带 } \\
\text { 草原 }\end{array}$ \\
\hline & VII & 10 & 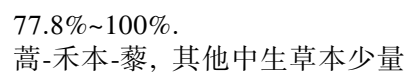 & $\begin{array}{l}2.6 \% \text { 2.72\% } \\
\text { 主要为松属未见落叶阔叶树种 }\end{array}$ & 未见 & $\begin{array}{l}7.51 \sim 13.00 \\
\text { 均值 } 9.52\end{array}$ & $\begin{array}{l}\text { 温凉较干的温带 } \\
\text { 草原 }\end{array}$ \\
\hline
\end{tabular}

后期(10500 9600 cal a BP)(表 4).

\section{5 讨论}

东胡林遗址是一处新石器文化早期遗址, 其地 貌部位清楚、遗址地层完整、文化内涵丰富. 考古学 家根据东胡林遗址出土石制品的分析认为, 在东胡 林人活动时期, 不但作为新旧石器过渡时期文化重 要标志的细石器得到极大的发展, 而且新石器也逐 渐有所增多, 呈现典型的新旧石器过渡的文化面貌.

新旧石器文化过渡的原因是多方面的. 本次研 究发现, 东胡林人活动期间属于新仙女木事件结束 之后的气候升温时期, 与华北其他地区一样 ${ }^{[25 ~ 28], ~}$ 当时这里的气候环境也发生了明显的变化, 出现了 温和较干的温带草原与比较温暖湿润的温带草甸草 原交互出现的植被面貌. 前人有关地文期的研究表 明, 在距今 1 万年前后, 华北地区随着气候的变暖和 水量的增加, 河流从马兰黄土堆积面上快速下切, 形 成马兰黄土台地和新的谷地(地文上称之为板桥期侵 蚀), 在新的谷地中, 由于强烈的加积作用, 河漫滩 发育, 堆积了厚层的河流沉积物 (地文上称之为鼻兰 期堆积 $)^{[29 ~ 32]}$. 从东胡林遗址的地貌结构来看, 当时 清水河也经历了同样的侵蚀和堆积过程, 东胡林人 主要活动在板桥期侵蚀造成的河谷中，与臬兰期的 河漫滩环境有密切的关系. 华北其他几处新旧石器 文化过渡时期的人类遗址, 如河北阳原的于家沟遗 址、山西吉县的柿子滩遗址、河南新密李家沟遗址等,
与东胡林遗址一样, 古人类的活动场所也都与板桥 期侵蚀造成的河谷地貌和臮兰期堆积有密切的关系. 由此我们推测, 新仙女木期之后气候升温期的出现 和板桥期侵蚀形成的河谷地貌, 可能是这一地区出 现新旧石器文化过渡的重要环境因素.

\section{6 结论}

综合以上地貌调查、剖面观察、年龄测定、粒度 分析和狍粉分析等多方面的工作, 并结合考古发掘 所获得的资料, 我们对东胡林人的生存环境得到如 下几点初步认识:

(1) 东胡林人主要活动在 11100 9600 cal a BP 期 间，恰好对应于新仙女木事件结束之后的气候升温 时期，也对应于板桥侵蚀之后的鼻兰堆积期.

(2) 东胡林人的活动遗迹主要分布在清水河三 级阶地的河流沉积物之中, 且见于多层河漫滩沉积 的顶面, 说明东胡林人主要生活在古清水河的河漫 滩上, 并随着河水的涨落和由此引起的地貌环境变 化, 不断改换自己的营地.

(3) 在东胡林人生活时期, 本区气候较前有明显 的改善, 出现了温带草甸草原和温带草原交替的生 态环境, 温和干燥——较为温暖湿润的气候环境, 河 漫滩上比较丰富的动植物资源, 适宜于原始人类在 此从事采集和狩猎活动.

(4) 在东胡林人生活期间, 以 $10500 \mathrm{cal} \mathrm{a} \mathrm{BP}$ 为 界, 地貌和气候环境都发生了一定的变化, 其中河流 
演变从第一次河流过程进人第二次河流过程，气候 环境由比较温干的温带草原为主转为以比较暖湿的 温带草甸草原为主. 与此同时, 从 $10500 \mathrm{cal} \mathrm{a} \mathrm{BP}$ 开
始，遗址中作为新旧石器过渡重要标志的细石器也 开始明显增多. 古文化的变化是否与环境的变化有 关，尚待进一步研究. 专业实验室和重离子所加速器质谱实验室共同完成，孢粉分析由中国地质科学院正定水文与工程地质研究所完 成, 作者在此一并致谢.

\section{参考文献}

1 Andersson J G. Topographical and archaeological studies in the Far East. In: Samlingarna Ö, ed. Bulletin of the Museum of Far Eastern Antiquities. Stockholm: BMFEA - Museum of Far Eastern Antiquities, 1939, 11: 7-22

2 叶良辅. 北京西山地质志. 地质专报(甲种), 1920, 1: 51-63

3 市美年, 袁复礼. 远东地形与考古之研究. 地质评论, 1940, 5: 119-131

4 赵希涛, 李容全. 北京斋堂地区第四纪沉积与地层. 中国科学院地质研究所集刊, 1981, 2: 112-122

5 傅先兰, 傅金沐, 李容全. 北京西山清水河侵蚀及其地貌环境演变. 北京师范大学学报, 1998, 1: 119-123

6 魏兰英. “清水侵蚀一马兰堆积”地文旋回的环境意义. 第四纪研究, 1998, 18: 284

7 殷春敏, 李容全. 北京西山清水河马兰台的形成时代与环境. 北京师范大学学报, 2000, 6: 835-839

8 郝守刚. 东胡林人的发现经过. 化石, 1988, 3: 18-19

9 周国兴, 尤玉柱. 北京东胡林村的新石器时代墓葬. 考古, 1972, 6: 12-15

10 赵朝洪. 北京市门头沟区东胡林史前遗址. 考古, 2006, 7: 3-8, 97-98

11 夏正楷, 陈福友, 陈戈, 等. 我国北方泥河湾盆地新一旧石器文化过渡的环境背景. 中国科学 D 辑: 地球科学, 2001, 31: 393-400

12 夏正楷, 陈戈, 郑公旺, 等. 黄河中游末次冰消期新旧石器文化过渡的气候背景. 科学通报, 2001, 46: 1204-1208

13 Mannion A M. Global Environmental Change. Singapore: Longman, 1997. 42-77

14 王文远, 刘家麒, Negendank J, 等. 热带湖光岩玛珥湖记录的末次冰消期东亚夏季风两步式的变化. 科学通报, 2000, 45: 860-864

15 周卫健, 安芷生, Poter S C, 等. 末次冰消期东亚和挪威海气候事件的对比. 中国科学 D 辑: 地球科学, 1997, 27: 260-264

16 E.布赖恩, 著, 刘东生, 译. 气候过程和气候变化. 北京: 科学出版社, 2004. 83-97

17 赵朝洪. 从旧石器时代向新石器时代过渡的清晰轨迹. 南方文物, 1995, 1: 28-37

18 郝守刚, 马学平, 夏正楷, 等. 北京斋堂东胡林人全新世早期遗址的黄土剖面. 地质学报, 2002, 76: 420-430

19 Reimer P J, Baillie M G L, Bard E, et al. IntCal04 terrestrial radiocarbon age calibration, 0-26 cal ka BP. Radiocarbon, 2004, 46: $1029-1058$

20 Reading H G. Sedimentary Environments: Processes, Facies, and Stratigraphy. London: Blackwell Science, 1978

21 成都地质学院陕北队. 沉积岩(物)粒度分析及其应用. 北京: 地质出版社, 1978. 1

22 陈中原, 严钦尚. 滹沱河平原段现代沉积结构、构造特征. 地理科学, 1982, 2: 210-221

23 高健, 严钦尚, 许世远. 滦河中游现代河流沉积构造与水动力的关系. 沉积学报, 1983, 1: 27-41

24 周昆叔. 对北京市附近两个埋藏泥炭沼泽的调查及其部分分析. 第四纪研究, 1965, 4: 118-134

25 李文渏. 中国第四纪植被与环境. 北京: 科学出版社, 1998

26 李月从, 王开发, 张玉兰. 南庄头遗址的古植被和古环境与人类活动的关系. 海洋地质与第四纪地质, 2000, 20: 23-30

27 孙湘君, 宋长青, 王奉瑜. 黄土高原南缘 10 万年以来的植被——陕西渭南黄土剖面的花粉记录. 科学通报, 1995, 40: 1222-1224

28 周昆叔. 北京平原第四纪晚期花粉分析及其意义. 地质科学, 1978, 1: 57-66

29 吴忱. 华北地貌环境及其形成演化. 北京: 科学出版社, 2008. 422-463

30 李吉均, 康成业. 中国第四纪冰期、地文期和黄土记录. 第四纪研究, 1989, 9: 269-276

31 李容全, 邱维理. 地文期与地文期研究. 第四纪研究, 2005, 25: 676-685

32 周昆叔. 中国北方全新世下界局部不整合——兼论板桥期侵蚀. 见: 刘家麒, 袁宝印, 编. 中国第四纪地质与环境. 北京: 海洋出 版社, 1997. 36-43 